\title{
Host switch by the Caribbean anemone shrimp Periclimenes rathbunae in Curaçao
}
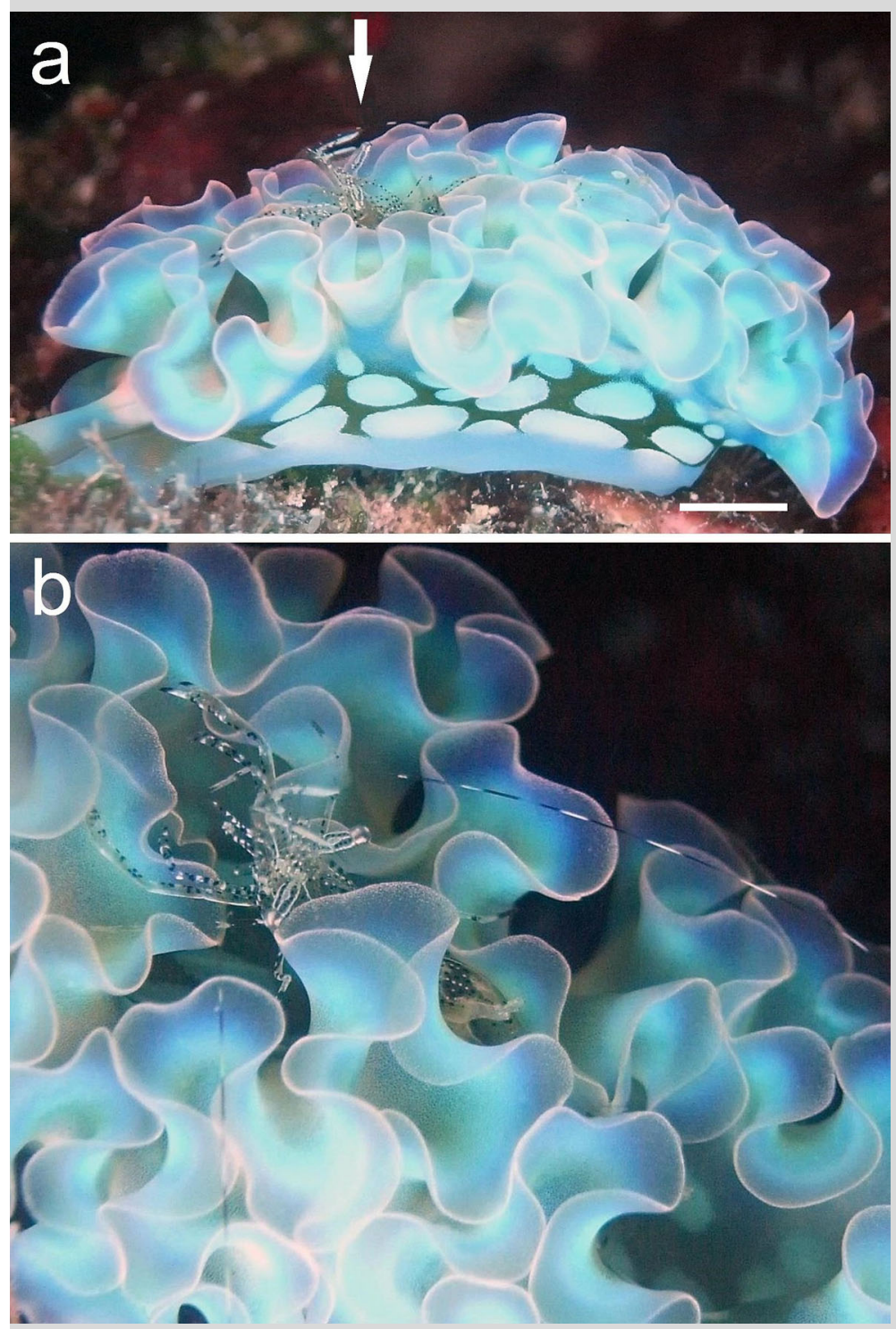

Fig. 1 Anemone shrimp, Periclimenes rathbunae, in association with the lettuce slug, Elysia crispata, at Curaçao. a Shrimp on the dorsal side of the slug (arrow), scale bar $0.5 \mathrm{~cm}$. b Same association in close-up view from above

B. W. Hoeksema $(\bowtie) \cdot$ C. H. J. M. Fransen

Naturalis Biodiversity Center, P.O. Box 9517, 2300 RA Leiden, The Netherlands

e-mail: bert.hoeksema@naturalis.nl
The anemone shrimp Periclimenes rathbunae Schmitt, 1924 (family Palaemonidae), is a common associate of shallowwater anthozoans in the tropical western Atlantic. It has been reported from several sea anemone species, an octocoral, a corallimorpharian, and a scleractinian coral (Brinkmann and Fransen 2016).

During a coral reef survey in Curaçao (1 April 2014), a previously unknown association was found between an individual of $P$. rathbunae and a lettuce slug, Elysia crispata Mörch, 1863 (Fig. 1). It occurred on the reef slope (6-8 m deep) of Playa Kalki on the island's northwestern tip $\left(12^{\circ} 22^{\prime} 30^{\prime \prime} \mathrm{N}, 69^{\circ} 09^{\prime} 28^{\prime \prime} \mathrm{W}\right)$, where this slug appeared to be abundant (ca. 40 observed individuals per 1-h dive). The shrimp's blue coloration matched that of its host, but it is usually dark red-brown (see, e.g., Brinkmann and Fransen 2016; Horká et al. 2016).

Elysia crispata is a polymorphic sacoglossan sea slug (infraclass Opisthobranchia) that eats algae in a wide range of habitats (Krug et al. 2016). In this case, the shrimp was positioned on top of its host between the dorsal frills, as if riding it (Fig. 1a, b).

Periclimenes rathbunae is the second shrimp species recorded as associate of an opisthobranch gastropod and the first one in the Atlantic. The other shrimp, Zenopontonia rex (Kemp, 1922), lives on Indo-Pacific reefs and is famous under its junior synonym, Periclimenes imperator Bruce, 1967. This species lives with echinoderm hosts as a juvenile but changes to nudibranch hosts as it matures (Horká et al. 2016). Periclimenes rathbunae also lives with a range of hosts, but it is not clear whether the association with $E$. crispata also results from an ontogenetic host switch.

Acknowledgements The authors are grateful to CARMABI, Curaçao, for hospitality and assistance.

\section{References}

Brinkmann BW, Fransen CHJM (2016) Identification of a new stony coral host for the anemone shrimp Periclimenes rathbunae Schmitt, 1924 with notes on the host-use pattern. Contrib Zool 85:437-456

Horká I, De Grave S, Fransen CHJM, Petrusek A, Duriš Z (2016) Multiple host switching events shape the evolution of symbiotic palaemonid shrimps (Crustacea: Decapoda). Sci Rep 6:26486

Krug PJ, Vendetti JE, Valdes A (2016) Molecular and morphological systematics of Elysia Risso, 1818 (Heterobranchia: Sacoglossa) from the Caribbean region. Zootaxa 4148:1-137 